\title{
INFESTATION OF LARNAEA CYPRINACEA (CRUSTACEA: CEPOPODA) IN DIFFERENT CATEGORIES OF COMMON CARP (CYPRINUS CARPIO) REARED IN SERBIA
}

\author{
Nikolina Novakov ${ }^{1 \star}$, Miroslav Ćirković ${ }^{2}$, Brankica Kartalović 2 , \\ Miloš Pelić ${ }^{2}$, Dimitrije Matić ${ }^{1}$, Dragana Ljubojević́ ${ }^{2}$, Biljana Božić ${ }^{2}$ \\ ${ }^{1}$ Faculty of Agriculture, Novi Sad, Serbia \\ ${ }^{2}$ Scintific Veterinary Institute „Novi Sad“ , Novi Sad, Serbia
}

\section{Abstract}

Lernaea cyprinacea in common carp and other warm water fishes is one of the major problems of aquaculture industry in Serbia. Infestations with Lernaea are most prevalent in the summer months and occur more commonly in stagnant or slow-moving water bodies. The optimal temperature range for Lernaea development is $26-28^{\circ} \mathrm{C}$. In the present study infection rate of $L$. cyprinacea in two different categories of fish pond cultured common carp was done. Pathological effects and control of the disease of infected fish were also followed. Fish sampling was done during the summer months of 2014, in 3 common carp fish ponds. One hundred twenty fish samples were collected from all carp ponds $(\mathrm{n}=120)$. After fish sampling collected Lernaea were transferred to the laboratory for parasite study. Prevalence of the infection was calculated for two age populations of carps. According to the obtained results, the parasite prevalence were significantly higher in carp fingerlings than in older carps $(\mathrm{P}<0.05)$. The highest numbers of parasites were found on fins and skin. Carps fry infestation of Lernaea caused intense inflammation and ulcers what leading to secondary bacterial and fungal infections. These secondary infections sometimes worsen and kill the fish. In carps for consumption $L$. cyprinacea infestation reduces the meat quality and lessening marketability of fish, because infected carps cause disgust of consumers and cannot be recommended for human consumption. Technological measures such as improvement of ambient conditions, adequate feed, optimum stock density, reduction of stress, good water quality and lime addition twice a week in quantity of $50 \mathrm{~kg} / \mathrm{ha}$ are the most efficacy in combatting this disease.

Key words: Lernaea cyprinacea, common carp, fingerlings, infestation

1* e-mail: nikolina@polj.uns.ac.rs 


\title{
INFESTACIJA SA LARNAEA CYPRINACEA (CRUSTACEA: CEPOPODA) KOD RAZLIČITIH KATEGORIJA RIBNJAČKOG ŠARANA (CYPRINUS CARPIO) GAJENOG U SRBIJI
}

\author{
Nikolina Novakov ${ }^{1 *}$, Miroslav Ćirković ${ }^{2}$, Brankica Kartalović ${ }^{1}$, Miloš \\ Pelić2, Dimitrije Matić ${ }^{1}$, Dragana Ljubojević́ , Biljana Božić ${ }^{2}$ \\ ${ }^{1}$ Poljoprivredni fakultet, Novi Sad, Srbija \\ ${ }^{2}$ Naučni institut za veterinarstvo „Novi Sad“, Novi Sad, Srbija
}

\section{Kratak sadržaj}

Lernaea cyprinacea kod šarana i drugih toplovodnih riba jedan je od važnih problema ribarske industrije u Srbiji. Infestacija sa parazitima iz roda Lernaea najčešće se javlja tokom letnjih meseci i to uglavnom u stajaćim i sporo tekućim vodama. Optimalna temperature za razvoj Lernaea kreće se od $26-28^{\circ} \mathrm{C}$. U ovom radu utvrđena je prevalenca lerneoze kod dve različite kategorije ribnjačkog šarana. Patološki efekti i kontrola bolesti kod zaraženih riba takođe su ispraćeni. Uzorkovanje riba rađeno je tokom letnjih meseci 2014 godine na tri šaranska ribnjaka. Ukupno je sakupljeno sto dvadeset uzoraka sa svih ribnjka $(n=120)$. Nakon uzorkovanja sakupljeni paraziti Lernaea prebačeni su u laboratoriju radi identifikacije. Prevalenca infestacije urađena je za dve različite starosne kategorije šarana. U skladu sa dobijenim rezultatima prevalence je bila značajno veća kod mladunaca šarana nego kod konzumnog šarana $(\mathrm{P}<0.05)$. Najveći broj parazita nađen je na perajima i koži. Kod infestacije šaranske mlađi sa L. cyprinacea dolazi do inflamacija i stvaranja ranica što pospešuje pojavu sekundarnih bakterijskih i gljivičnih infekcija, koje mogu da dovedu do uginuća mlađi. Kod konzumnog šarana infestacija sa $L$. cyprinacea smanjuje kvalitet mesa i sbosobnost ribe da se plasira na tržište, jer takva riba izaziva gđenje potrošača što je čini neupotrebljivom za ishranu ljudi. U kontroli ovog obolenja najbolje je primenjivati tehnološke mere poput, adekvatne ishrane, optimalne gustine nasada, smanjenja stresa, dobrog kvaliteta vode i dodavanja kreča u količini od $50 \mathrm{~kg} / \mathrm{ha}$, dva puta nedeljno.

Ključne reči: Lernaea cyprinacea, šaran, mlađ, infestacija

\section{INTRODUCTION}

Lernaea cyprinacea Linnaeus, 1758 (Crustacea: Copepoda), commonly known as "anchor worm", is an important crustacean parasite of freshwater 
fish that has a wide geographic range. Parasite is widely distributed in Africa, Asia, North America and Europe, and there are reports about incidence of it in fish ponds and natural aquatic ecosystems (Demaree, 1967; Dorovskikh, 1993; Hoffman, 1999; Silva-Souza et al., 2000; Nagasawa et al., 2007; Hassan et al., 2008; Ćirković and Novakov, 2013). This parasite reproduces continuously in warm season and its adult form sets on the skin of common carp, grass carp, bighead carp and silver carp. L. cyprinacea have nine stages in the life cycle, including three free-living naupliar stages, five copepodid stages and one adult stage. After mating on the fish host, the males die and females metamorphose and insert their anterior body into the host tissue and then produce eggs (Nagasawa et al., 2007; Barson et al., 2008). Also, the parasite does not need an intermediate host for growth and development. The highest incidence of Lerneaea infestation is in warm season when the temperature is suitable for growth and reproduction of this parasite, i.e., $22-30{ }^{\circ} \mathrm{C}$. At this temperature the life cycle completes within 17-22 days (Nagasawa et al., 2007; Barson et al., 2008; Madanire Moyo and Barson, 2010). If temperatures fall below $20^{\circ} \mathrm{C}$, juvenile Lernaea are unable to complete their development and at $14^{\circ} \mathrm{C}$, females will not reproduce. However, adult females can overwinter on the fish host, producing eggs when water temperatures warm up in the spring. Lernaea cyprinacea have serious deleterious effects on their freshwater fish hosts (Hoffman, 1999). Lernaea creates skin damages, reduces growth and osmoregulation ability, and also influences behavior and decreases fish resistance against stressful condition. Infection by the Lernaea can decrease the marketability of older fish intended for consumption. Lerneosis occurs in different age categories of common carp. The relationship between the size of cyprinid fishes and L. cyprinacea infections has been studied by Amin et al., (1973), Dorovskikh, (1993) and Pérez-Bote, (2000).

The main goal of the present study was to determine infection rate of $L$. cyprinacea in two different categories of fish pond cultured common carp, i.e., carp fry and carp for consumption. We also aimed to investigate its pathological effects, control of the disease and marketability of infected fish.

\section{MATERIALS AND METHODS}

The investigation was carried out during 2014, on 3 common carp fish farms in Serbia, Vojvodina province. Fish material included 1- to 4 yr-old pond-cultured common carp (Cyprinus carpio). Sampling at the fish farms was conducted out between June and August within the intervals of 7-14 days. One hundred twenty fish samples were collected from all carp ponds $(n=120)$. 
From each pond were collected 20 samples of young (fingerlings) and 20 samples of older (for consumption) fish.

The sampling program was done using nets. The external body surfaces as well as the gill chamber and mouth cavities of each fish were examined for the presence of adult parasite and penetration sites for anchored cepopods were localized. A method used by Barson et al., (2008) was used for L. cyprinacea parasite identification. All live and healthy fish were returned to the fish pond.

Data analysis was performed to determine significant differences in the two age categories of carps. Statistica 12 software and Excel (Microsoft Excel, 2007) were used for data analysis. Post-hoc Duncan tests were used for statistical analysis of differences. $\mathrm{P} \leq 0.05$ was considered statistically significant.

\section{RESULTS AND DISCUSSION}

The infection parameters (the number of parasitized fish and prevalence) obtained of L. cyprinacea infestation on the 3 cyprinid fish ponds are given in Table 1. L. cyprinacea prevalence (Tabble 1, Graph 1) were significantly higher in carp fingerlings than in older carps which are ready for consumption $(\mathrm{P}<0.05)$. The highest numbers of parasites were found on fins (Figure 1), and skin. L. cyprinacea was not found in the nasal and oral cavities.

Table 1. Prevalence, number of positive and negative carps infected with L. cyprinacea

\begin{tabular}{|c|c|c|c|c|c|}
\hline \multirow{2}{*}{$\begin{array}{c}\text { Age } \\
\text { categories }\end{array}$} & \multirow{2}{*}{$\begin{array}{l}\text { Fish } \\
\text { ponds }\end{array}$} & \multirow{2}{*}{$\begin{array}{l}\text { Number of } \\
\text { sampled fish }\end{array}$} & \multicolumn{2}{|c|}{ Result } & \multirow{2}{*}{$\begin{array}{l}\text { Prevalen- } \\
\text { ce }(\%)\end{array}$} \\
\hline & & & Positive & Negative & \\
\hline \multirow{3}{*}{$\begin{array}{c}\text { Carp } \\
\text { fingerlings }\end{array}$} & I & 20 & 3 & 17 & \multirow{3}{*}{$16,6 \pm 3.75$} \\
\hline & II & 20 & 4 & 16 & \\
\hline & III & 20 & 3 & 17 & \\
\hline \multirow{3}{*}{$\begin{array}{l}\text { Carps for } \\
\text { consump- } \\
\text { tion }\end{array}$} & I & 20 & 0 & 20 & \multirow{3}{*}{$5 \pm 2.21^{b}$} \\
\hline & II & 20 & 2 & 18 & \\
\hline & III & 20 & 1 & 19 & \\
\hline
\end{tabular}

Prevalence values are mean \pm SD $(n=60)$. ${ }^{\mathrm{a}, \mathrm{b}}$ Means with different letter indexes are significantly different $(\mathrm{P} \leq 0.05)$ 


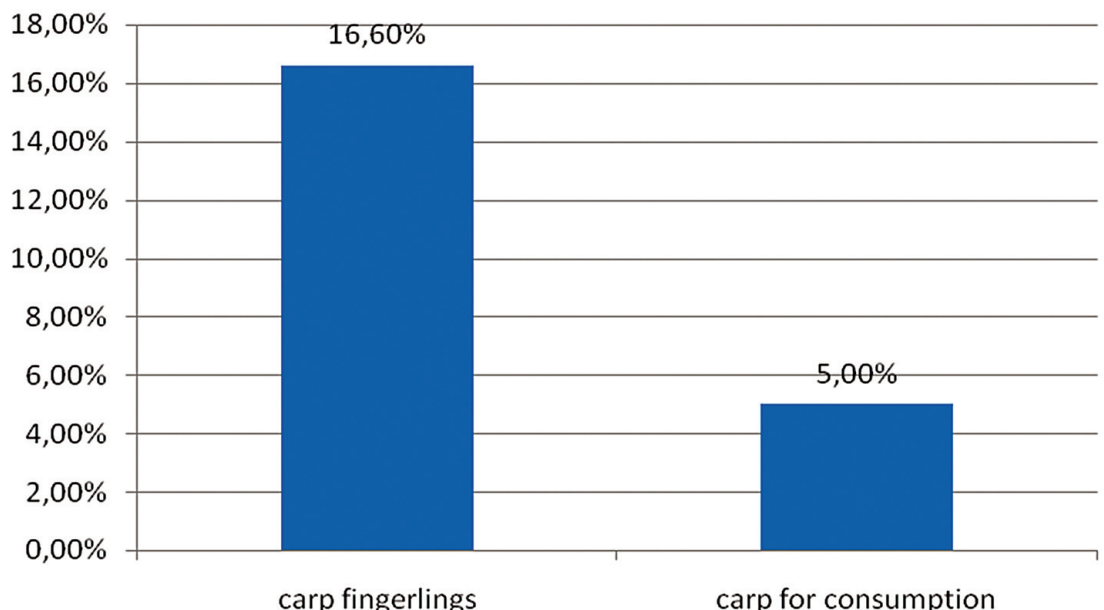

Chart 1. Comparison of L. cyprinacea percent prevalence between carp fingerlings and carps ready for consumption

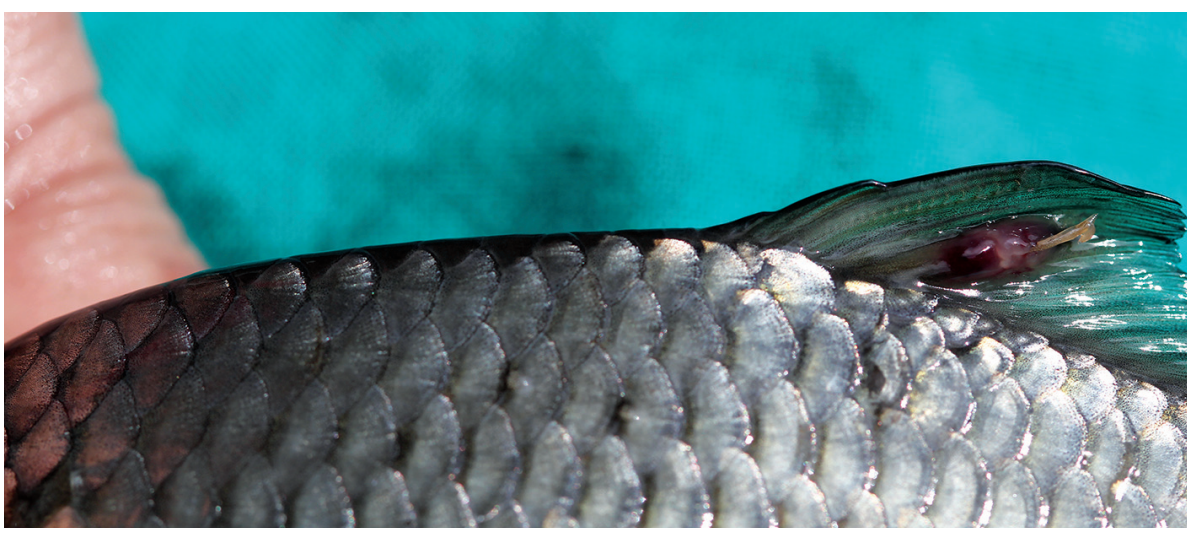

Figure 1. L. cyprinacea anchored to the dorsal fin of the carp fingerling.

Controlling many important parasitic diseases is still far from satisfactory condition, and more supervision is needed. Aquaculture development over recent decades and concerns about the prevalence of parasites have caused experts' more attention to this problem created by parasites and their importance in decreasing aquatic animals reproduction power. In general, the most important common crustacean parasites of fresh water fishes in Serbia is $L$. cyprinacea. Lernaea infestations are particularly common in cyprinids, especially in common carp, but also in koi, goldfish, and other related carp, altho- 
ugh numerous other freshwater species are susceptible (Lester and Hayward, 2006). It is often present in all categories and species of freshwater fishes. So, it is necessary to pay attention to the incidence, pathological effects and control of this parasite, what is essential for carp aquaculture enhancing. In the present study prevalence was $16.6 \%$ in carp fingerling, respectively $5 \%$ in carps for consumption. This is because the parasites usually occur more frequently in younger than in older category of common carp, especially when fry are cultured in high stock density with poor body condition (Ćirković and Novakov, 2013). The parasite in cyprinid species seems to be mainly located in the fins. In the present study, the preferred site was the fins what is in accordance with the studies of Amin et al., (1973); Saraiva and Valente, (1988); Sterling et al., (1995); Dorovskikh (1996); Pérez-Bote (2000). The pathogenic effect comes down to the inflammation of the affected tissue. At the attachment places there is inflammation and ulcers with narrow white brim. These are the places which may become inhabited by pathogenic bacteria and fungi. Infected fingerlings are weak and anaemic (Ćirković and Novakov, 2013). In older caterogy the major problem is marketability of fish. Since this parasite is the arthropod that are found on the skin it is easily visible, should be removed before harvesting of fish. Otherwise, such carps cause disgust of consumers and cannot be recommended for human consumption. The most important is control of disease. In order to prevent the disease it is necessary to rear young fish separately from other fish categories and prevent weed fishes which can be source of the infection from entering fish pond (Ćirković et 1., 2015). Several therapies are available for control of lernaeids; however, options are very limited for food fish and pond production (Francis-Floyd and Reed, 2011). The most efficacy measure is application of lime twice a week in concentration of $50 \mathrm{~kg} / \mathrm{ha}$. The improvement of ambient conditions, adequate feed and optimum stock density deliver best results.

\section{CONCLUSION}

Lerneosis is one of the most common diseases in freshwater fishes. L. cyprinacea prevalence was $16.6 \%$ in carp fingerling, respectively $5 \%$ in carps for consumption. Lernea in carp fry cause inflammation and ulcers at the attachement place which result in offten pathogenic bacteria and fungi infections. The major problem of L. cyprinacea infestation in older cytegory is reducing the quality and lessening marketability of fish. Technological measures (optimal density, feeding, reduction of stress, good water quality) and lime addition are key factor in combatting this disease. 


\section{LITERATURE}

1. Amin M., Balsano S., Pfalzgraf A: Lernaea cyprinacea Linn. (Copepoda: Crustacea) from Root River, Wisconsin, fishes. Am Midl Nat, 89, 484-487, 1973.

2. Barson M., Mulonga A., Nhiwatiwa T.: Investigation of a parasitic outbreak of Lernaea cyprinacea Linnaeus (Crustacea: Copepoda) in fish from Zimbabwe. Afri.J.Zoo., 43, 175-183, 2008.

3. Ćirković M., Novakov N.: Parazitske bolesti ciprinidnih riba, Naučni institut za veterinarstvo Novi Sad, Elman štampa, 2013.

4. Ćirković M., Novakov N., Kartalović B., Pelić M., Jovanić S., Božić B., Đorđević V.: Ichthyophthiriosis-cause of significant losses of carp fingerlings, Arhiv veterinarske medicine, 8,1, 3-12, 2015.

5. Demaree S.: Ecology and external morphology of Lernaea cyprinacea, L. Am Mid Nat, 76,416 - 427, 1967.

6. Dorovskikh N.: The distribution of Lernaea cyprinacea (Copepoda: Lernaeidae) in a crucian carp population. Parazitologiya, 27,90-96, 1993.

7. Dorovskikh N.: Location of Lernaea cyprinacea (Copepoda: Lernaeidae) on the body of crucian carp. Parazitologiya, 30,540-544, 1996.

8. Francis-Floyd R., Reed P.: Lernea (Anchorworm) Infections in Fish, Institute of Food and Agricultural Sciences, University of Florida, UF/IFAS Extension publications, 2011.

9. Hassan M., Beatty J., Morgan I., Doupe G., Lymbery J.: An introduced parasite, Lernaea cyprinacea L., found on native fresh-water fishes in South West of Western Australia. J R Soc West Aust, 91,149 -153. 2008.

10. Hoffman L.: Parasites of North American fresh water fishes, 2nd edition, Comstock Publishing Associates, Division of Cornell University Press, Ithaca and London. 1999.

11. Lester G., Hayward J.: Phylum Arthropoda. In Fish Diseases and Disorders, vol. 1: protozoan and metazoan infections, second ed. P.T.K. Woo, editor. CAB International, London, England. 466-565, 2006.

12. Madanire-Moyo G., Barson M.: Diversity of metazoan parasites of the African catfish Clarias gariepinus (Burchell, 1822) as indicators of pollution in a subtropical African river system. J. Helminthol., 84, 216-227, 2010.

13. Nagasawa K., Inoue A., Myat S., Umino S.: New host records for Lernaea cyprinacea (Copepoda), a parasite of freshwater fishes with a checklist of the Lernaeidae in Japan (1915 -2007). J. Grad. Sch. Biosph. Sci., 46, 21-23, 2007.

14. Pérez-Bote L.: Occurrence of Lernaea cyprinacea (Copepoda) on three native cyprinids in the river Guadiana (SW Iberian Peninsula). Res Rev Parasitol, 60, 135-136, 2000. 
15. Saraiva A., Valente N., Black spot disease and Lernaea sp. Infestation on Leuciscus cephalus L (Pisces: Cyprinidae) in Portugal. Bull Eur Assoc Fish Pathol 8,7-8, 1988.

16. Silva-Souza T., Almeida C., Machado M.: Effect of the infestation by Lernaea cyprinacea Linnaeus 1758 (Copepoda, Lernaeidae) on the leucocytes of Schizodon intermedius Garavello and Britski 1990 (Osteichthyes, Anostomidae). Rev. Bras. Biol.,60, 217-220, 2000.

17. Sterling E., Carbonell E., Estellés-Zanón J., Chirivella J.: Estudio estacional del parasitismo por Lernaea cyprinacea en la madrilla Chondrostoma toxostoma miegii (Pisces: Cyprinidae) en un afluente del río Ebro. Proc 4th Iber Cong Parasitol, Santiago de Compostela, Spain, 90-91, 1995.

Primljeno: 20.12.2015.

Odobreno: 15.01.2016. 